\title{
PERAN CATHEPSIN D INHIBITOR PADA TERAPI KANKER
}

\author{
Devi Maulina ${ }^{1}$ \\ maulinadevi2011@gmail.com, Prodi DIII Farmasi, Politeknik Kesehatan Hermina, Jakarta, Indonesia
}

\begin{abstract}
Cathepsin D was marker of poor prognosis in cancer and increased levels of Cathepsin D associated with increasing malignancy of cancer cells. Inhibition of Cathepsin D is a potential target for treating cancer. This study is a systematic review of the role of cathepsin D inhibitors in cancer therapy. Data was obtained from literature searches by collecting literature from databases such as Scopus, Pubmed, Google Scholar and Science Direct from 2016-2020.
\end{abstract}

Keyword: cathepsin D inhibitor, cancer, systematic review

\begin{abstract}
Abstrak
Cathepsin D dianggap sebagai penanda memburuknya prognosis pada kanker dan peningkatan kadar Cathepsin D berhubungan dengan meningkatnya keganasan sel kanker. Hal ini tentu saja mendasari bahwa penghambatan terhadap Cathepsin D merupakan target potensial untuk mengobati kanker. Penelitian ini merupakan sistematika review peran cathepsin D inhibitor pada terapi kanker. Data diperoleh dari penelusuran literatur dengan cara pengumpulan literature dari database seperti Scopus, Pubmed, Google Scholar dan Science Direct dari tahun 20162020.
\end{abstract}

Kata kunci: cathepsin D inhibitor, kanker, sistematika review

\section{PENDAHULUAN}

Kasus baru kanker di seluruh dunia diperkirakan 19,3 juta kasus (18,1 juta tidak termasuk kanker kulit non melanoma) dan hampir 10,0 juta kematian disebabkan kanker (9,9 juta tidak termasuk kanker kulit non melanoma) (Sung et al., 2021). Sementara itu di Indonesia data Riset Kesehatan Dasar (Riskesdas) tahun 2018 menunjukkan prevalensi kanker sebesar 1,79 per 1000 penduduk, naik dari tahun 2013 sebanyak 1.4 per 1000 penduduk (Kemenkes RI, 2018)

Kanker merupakan penyakit kompleks dengan ciri umum pertumbuhan sel yang tidak terkendali, menghindari apoptosis dan hilangnya regulasi siklus sel (Baskar et al., 2014). Sel kanker memulai tumor dengan adanya mutasi pada onkogen dan supresor tumor gen. Sel kanker membelah lebih cepat daripada sel normal dan tingkat pertumbuhannya dilaporkan berkorelasi dengan peningkatan perubahan metabolik selama transformasi sel (Baskar et al., 2014). Sekitar 5-10\% dari semua kasus kanker disebabkan oleh cacat genetik, sedangkan sisanya 90-95\% disebabkan pada lingkungan dan gaya hidup. Faktor gaya hidup meliputi merokok, diet (makanan gorengan, daging merah), alkohol, paparan sinar matahari, polusi lingkungan, infeksi, stres, dan obesitas (Chaudhary $\mathrm{H}$ et al., 2012).

Perawatan yang saat ini dilakukan untuk terapi kanker terdiri dari terapi radiasi, operasi, kemoterapi, imunoterapi dan terapi hormone (Baskar et al., 2012). Kemajuan yang luar biasa telah dicapai dalam pengembangan dan pengobatan kanker dalam beberapa tahun terakhir. Namun dengan meningkatnya kejadian kanker, manajemen klinis kanker terus menjadi tantangan bagi abad ke-21. Meskipun penelitian dan metode pengobatan telah berkembang pesat untuk penanganan penyakit kanker, namun angka kematian pasien kanker tetap tinggi, hal ini terutama disebabkan karena proses metastasis dan invasi kanker. Telah diketahui sebelumnya bahwa perjalanan dari kanker sangat kompleks, meliputi onkogenesis, imunitas pejamu, angiogenesis, invasi dan metastasis (Tobias \& Hochhauser, 2009).

Invasi dan metastasis tumor berhubungan dengan aktivitas proteolitik enzim protease (Park et al., 2020). Salah satunya adalah Cathepsin D yang merupakan enzim protease lisosom 
yang terletak dihampir semua sel dan jaringan pada mamalia. (Tan et al., 2013). Ekspresi dan sekresi Cathepsin D secara berlebihan oleh tumor ganas terlibat dalam invasi tumor, proliferasi, metastasis, dan menghambat apoptosis (Tan et al., 2013). Analisis kuantitatif Cathepsin D pada sel kanker payudara menunjukkan bahwa konsentrasi Cathepsin D di sitoplasma berkorelasi dengan ukuran, diferensiasi, dan metastasis tumor padat. Penelitian sebelumnya membuktikan bahwa lebih dari 75\% sel-sel kanker karsinoma duktus invasif menunjukkan ekspresi Cathepsin D (Lubis et al., 2012). Cathepsin D dianggap sebagai penanda prognosis independen pada jenis kanker dan peningkatan Cathepsin D berhubungan dengan meningkatnya keganasan dari kanker termasuk kanker payudara, kanker ovarium, kanker lambung dan kanker prostat. Hal ini tentu saja mendasari bahwa Cathepsin D merupakan target potensial untuk mengobati kanker (Ketterer et al., 2020; Xu et al., 2017).

\section{METODE}

Penelitian ini merupakan sistematika review peran cathepsin D inhibitor pada terapi kanker. Data diperoleh dari penelusuran literatur dengan cara pengumpulan literature dari database seperti Scopus, Pubmed, Google Scholar dan Science Direct dari tahun 2016-2020.

\section{HASIL DAN PEMBAHASAN}

Cathepsin D merupakan acidic lysosomal protease yang dapat ditemukan pada endosom dan lisosom sel mamalia dan dikode oleh gen CTSD. Gen cathepsin D manusia mengandung 9 ekson, dan terletak pada kromosom 11p15 (Xu et al., 2017).

Cathepsin D disintesis dalam retikulum endoplasma (RE) kasar sebagai proprocathepsin D berukuran 30-50 kDa dalam bentuk inaktif. Pada jalur RE/Golgi, sinyal urutan peptida dibelah dan procathepsin D (pCD) dilapisi glikosilasi pada residu asparagin. Selanjutnya, procathepsin D ditargetkan pada struktur vesikular intraseluler (lisosom, endosom). Saat memasuki kompartemen asam ini, pembelahan propeptida menghasilkan suatu formulasi enzim aktif rantai tunggal. Proses proteolitik lebih lanjut menghasilkan Cathepsin D matang yang terdiri dari rantai berat dan rantai ringan. Pada sel kanker procathepsin D yang tidak aktif secara enzimatik disekresikan ke dalam ruang ekstraselular. Hal ini memungkinkan procathepsin D dapat dikonversi di lingkungan ekstraseluler yang bersifat asam menjadi pseudocathepsin D yang aktif secara enzimatik dengan proses autokatalitik. Hipotesanya pseudocathepsin D dapat diproses oleh protease lain menjadi Cathepsin D rantai tunggal atau selanjutnya menjadi dua rantai Cathepsin D. Pada tumor, bentuk aktif Cathepsin D juga bisa dilepaskan dari sel nekrotik. Adanya bentuk Cathepsin D aktif tertentu di ruang ekstraselular tumor padat secara in vivo dapat diasumsikan namun tidak pernah dibuktikan secara langsung (Masson et al., 2010).

Cathepsin D berperan penting dalam tahap progresi sel kanker dengan mekanisme merangsang proliferasi sel kanker, invasi dan metastasis, angiogenesis tumor, dan penghambatan apoptosis sel kanker.(Benes et al., 2008) Penelitian sebelumnya mengemukakan bahwa Cathepsin D dapat merangsang proliferasi sel kanker melalui aktivitas enzimatik. Beberapa growth factor, growth factor receptor dan komponen matriks ekstraselular (ECM) dapat ditemukan pada substrat Cathepsin D. Selain itu, Cathepsin D dapat mencerna berbagai kemokin dan karena itu dapat menurunkan respon kekebalan anti-tumor. $\mathrm{pH}$ ekstraseluler sel tumor cukup asam dan procathepsin D yang disekresikan dapat dikonversi menjadi enzim aktif dalam lingkungan ekstraselular(Reinheckel et al., 2008).

Mekanisme invasi dan metastasis sel kanker oleh Cathepsin D melalui degradasi matriks ekstraseluler, aktivasi protease, dan memotong faktor adhesi antar sel. Mekanisme invasi lainnya adalah melalui degradasi langsung komponen matriks ekstraseluler sehingga tercipta ruang bagi migrasi sel invasif. Cathepsin D diketahui dapat memotong komponen membran basalis atau matriks ekstraseluler antara lain laminin, kolagen tipe IV, fibronektin, dan 
tenascin-C. Dalam progresi tumor, cathepsin seringkali mengalami translokasi ke permukaan sel atau disekresi ke ruang ekstraseluler, memudahkan akses cathepsin terhadap protease lain di permukaan sel atau substratnya dalam matriks ekstraseluler. Cathepsin D juga berperan dalam aktivasi protease lain dengan memulai kaskade proteolitik yang berujung pada pemecahan beberapa target, yang secara keseluruhan memperkuat proses invasi tumor. Eksperimen in vitro menunjukkan bahwa cathepsin memotong dan mengaktifkan MMP-1 dan MMP-3, mengkonversi prekursor aktivator plasminogen tipe urokinase (uPA) menjadi enzim aktif, yang kemudian mengkatalisis pemotongan plasminogen menjadi plasmin. Plasmin adalah protease serine spektrum luas yang dapat langsung mendegradasi komponen matriks ekstraseluler dan mengaktifkan MMP lainnya Reinheckel et al., 2008).

Pada sel-sel kanker, cathepsin D yang berlebihan bisa terakumulasi dalam sel-sel yang dapat mempengaruhi kapasitas degradasi sel dan enzim tersebut dilepaskan secara berlebihan di lingkungan mikro tumor. Oleh karena itu, tindakan penghambatan cathepsin D memerlukan pengembangan inhibitor yang dapat menargetkan cathepsin D di ekstraseluler, dan/atau intraselular yang terletak di berbagai bagian sel (misalnya vesikel intraseluler, sitosol, atau nukleus) (Reinheckel et al., 2008).

Angiogenesis dan invasi adalah dua tahap dalam perkembangan tumor yang sejak lama diketahui membutuhkan aktivitas proteolitik. Proses pembentukan pembuluh darah baru, angiogenesis atau neovaskularisasi, sangat penting untuk pertumbuhan tumor dengan ukuran lebih dari 1-2 $\mathrm{mm}^{3}$. Angiogenesis umumnya dipicu oleh dilepaskannya faktor pertumbuhan proangiogenik, seperti VEGFdari tumor. Sel endotel bermigrasi ke lesi yang bertumbuh dan membelah serta berdiferensiasi guna membentuk pembuluh darah baru, yang dapat didukung oleh sel otot polos. Induksi proteolisis diperlukan dalam proses degradasi terkontrol matriks ekstraseluler dan membran basalis vaskuler, sebuah tahap penting dalam pertumbuhan darah. Pada akhirnya, proses ini tergantung pada keseimbangan antara faktor proangiogenik (vEGF, FGFs, protease, dan lain-lain) dan antiangiogenik (endostatin, tumstatin, thrombospondin, dan lain-lain) (Reinheckel et al., 2008).

Cathepsin D mampu mendegradasi TIMPs, enzim yang dapat mengendalikan laju neoangiogenesis jaringan, penyebab pertumbuhan pembuluh darah yang tidak terkendali pada jaringan tumor (Gacko et al., 2007). Peran Cathepsin D dalam menghambat apoptosis berdasarkan pada fungsi katalitiknya. Berchem dkk, menyatakan bahwa ekspresi berlebih CTSD pada kultur sel D3Y1-Ad12 menyebabkan sel tersebut menghindar dari apoptosis karena fungsi katalitik cathepsin D (Minarowska et al., 2007).

Peran Cathepsin D Inhibitor pada kanker dapat dijelaskan melalui mekanisme sebagai berikut:

\section{Menghambat Aktivitas Proteolitik Cathepsin}

Aktivitas Cathepsin D dapat dihambat oleh analog struktural dari substrat sintetis dimana L-asam amino digantikan oleh D-asam amino. Segmen propeptida cathepsin D yang terbelah selama aktivasi zymogen, dilaporkan dapat menghambat procathepsin $\mathrm{D}$ dengan menghalangi situs aktif pada $\mathrm{pH}$ netral. Pada $\mathrm{pH}$ tinggi, konformasi yang stabil dari cathepsin $\mathrm{D}$ yang berada dalam situs aktif tetap di hambat. Fragmen peptida yang berasal dari propeptida telah menunjukkan beberapa potensi penghambatan cathepsin D yang telah mature. Pepstatin A, salah satu inhibitor aspartik protease yang diproduksi oleh mikroorganisme, merupakan inhibitor cathepsin D polipeptida yang paling potensial. Pepstasin A merupakan heksa-peptida yang mengandung asam amino yang tidak biasa, statin (asam Sta, (3S, 4S) -4-amino-3-hydroxy6-methylheptanoic), dan memiliki urutan Iva-Val-Val-Sta-Ala- Sta yang awalnya diisolasi dari kultur berbagai spesies Actinomycesdue dengan kemampuannya untuk menghambat pepsin pada konsentrasi picomolar. Peptasin A kemudian ditemukan sebagai penghambat potensial 
dari hampir semua protease asam. Pepstatin biasanya digunakan untuk mempelajari peran cathepsin D secara in vitro dan di dalam sel. Beberapa penelitian tampaknya menunjukkan bahwa pepstatin A yang diberikan secara in vivo menginduksi penurunan metastasis yang signifikan. Penghambatan aktivitas cathepsin D oleh tripeptida yang mengandung analog statin juga telah dilaporkan. Inhibitor cathepsin D polipeptida juga telah diidentifikasi di banyak tanaman, seperti daun tomat dan umbi kentang. Inhibitor cathpsin D juga diproduksi oleh hewan yang lebih rendah, seperti equistatin dari Actinia equina yang juga dapat menghambat aktivitas sistein cathepsin. Menariknya, telah ditunjukkan bahwa asam deoksiribonukleat (fragmen DNA) dapat menghambat aktivitas proteolitik cathepsin D (Gacko et al., 2007).

2. Menghambat aktivitas pengikatan pada resptor M6P

Studi tentang cathepsin D yang disekresikan sebagai mitogen melalui aktivitas pengikatan protein pada kanker menunjukkan keterlibatan bagian profragmen cathepsin D dalam interaksi dengan reseptor permukaan sel yang tidak diketahui. Procathepsin D yang disekresikan juga dapat bertindak sebagai mitogen melalui interaksinya dengan M6P bagian dari reseptor M6P / IGF-2, menggeser IGF2 dari reseptor IGF1, dan menyebabkan aktivasi jalur reseptor IGF1 mitogenik. ${ }^{\mathrm{D} 231 \mathrm{~N}}$ cathepsin $\mathrm{D}$ mutan yang tanpa aktivitas proteolitik masih bersifat mitogenik untuk sel kanker dan fibroblas baik secara in vitro dalam matriks tiga dimensi (3D), dan pada athymic nude mice. Temuan ini menunjukkan bahwa procahepsin-D dapat bertindak sebagai protein pengikat ekstraselular dengan secara langsung atau tidak langsung memicu reseptor permukaan sel yang belum teridentifikasi. Selain menggunakan inhibitor aktivitas katalitik klasik, menargetkan procathepsin pada matriks ekstraseluler dapat menjadi perspektif baru dalam penghambatan terapeutik fungsi protease pada kanker (Gacko et al., 2007).

3. Sebagai Pengganti Substrat Cathepsin D

Penemuan substrat fisiologis cathepsin D menjadi target untuk terapi kanker. Untuk memahami fungsi protease, sangat penting untuk mengidentifikasi substrat enzim tersebut. Cathepsin D memotong secara khusus ikatan -Phe-Phe-, -Leu-Tyr-, -Tyr-Leu-, dan -Phe-Tyrdalam rantai peptida yang mengandung paling sedikit lima asam amino pada $\mathrm{pH}$ asam. Peptida ini mengandung asam L-amino, dan juga mengandung residu asam amino hidrofobik di tempat yang dibelah oleh cathepsin $D$. Selain perannya sebagai enzim pendegradasi protein utama pada lisosom dan fagosom, telah ditunjukkan bahwa cathepsin D juga dapat mengaktifkan prekursor protein aktif biologis, seperti prolaktin dan osteopontin pada sel khusus. Beberapa substrat cathepsin D telah dilaporkan secara in vitro, namun tidak ada substrat endogen cathepsin D pada kanker yang telah diidentifikasi dengan jelas. Dalam proteomik, himpunan protein yang dapat dihidrolisis oleh protease dinamai substratnya degradom atau degradomik. Sebuah metode yang disebut (TAILS) baru-baru ini dikembangkan untuk mengidentifikasi substrat protease ekstraselular dan membran menggunakan pelabelan dan spektrometri massa iTRAQ. Pendekatan proteomik yang kuat ini, yang memungkinkan ditemukannya degradasi substrat MMP-2, juga dapat diterapkan pada identifikasi substrat cathepsin D menggunakan sel baik yang mengekspresikan atau tidak mengekspresikan cathepsin D (Gacko et al., 2007).

\section{PENUTUP}

Cathepsin D yang merupakan enzim protease lisosom yang terletak dihampir semua sel dan jaringan pada mamalia. Ekspresi dan sekresi Cathepsin D secara berlebihan oleh tumor ganas terlibat dalam kemajuan invasi tumor, proliferasi, metastasis, dan apoptosis. Cathepsin D telah dianggap sebagai penanda prognosis independen pada jenis kanker dan peningkatan kadar Cathepsin D berhubungan dengan meningkatnya keganasan dari kanker termasuk kanker payudara, kanker ovarium, kanker lambung dan kanker prostat. Hal ini mendasari bahwa Cathepsin D merupakan target potensial untuk mengobati kanker dengan pengembangan Cathepsin D inhibitor. Peran dari cathepsin D inhibitor dalam terapi kanker antara lain 
menghambat aktivitas proteolitik cathepsin $\mathrm{D}$, menggangu aktivitas pengikatan dengan reseptor mannosa 6 fosfat (M6P) dan sebagai pengganti substrat cathepsin D.

\section{DAFTAR PUSTAKA}

Baskar, R., Dai, J., Wenlong, N., Yeo, R., \& Yeoh, K. W. (2014). Biological response of cancer cells to radiation treatment. Frontiers in Molecular Biosciences, 1(NOV), 1-9. https://doi.org/10.3389/fmolb.2014.00024

Baskar, R., Lee, K. A., Yeo, R., \& Yeoh, K. W. (2012). Cancer and radiation therapy: Current advances and future directions. International Journal of Medical Sciences, 9(3), 193-199. https://doi.org/10.7150/ijms.3635

Benes, P., Vetvicka, V., \& Fusek, M. (2008). Cathepsin D-Many functions of one aspartic protease. Critical Reviews in Oncology/Hematology, 68(1), 12-28. https://doi.org/10.1016/j.critrevonc.2008.02.008

Chaudhary H, K, J. P., D, T., \& K, P. (2012). Cathepsin D: A Novel Target for Apoptotic Induction, as a Future Anti-Cancer Therapy: a Review Journal of Physiology and Pharmacology Advances Cathepsin D: A Novel Target for Apoptotic Induction, as a Future Anti-Cancer Therapy: a Review. J Phys Pharm Adv, 2(22), 87-9687.

Gacko, M., Minarowska, A., Karwowska, A., \& Minarowski, Ł. (2007). Cathepsin D inhibitors. Folia Histochemica et Cytobiologica, 45(4), 291-313. https://doi.org/10.5603/4501

Kemenkes RI. (2018). Hasil Riset Kesehatan Dasar Tahun 2018. Kementrian Kesehatan RI, 53(9), 1689-1699.

Ketterer, S., Mitschke, J., Ketscher, A., Schlimpert, M., Reichardt, W., Baeuerle, N., Hess, M. E., Metzger, P., Boerries, M., Peters, C., Kammerer, B., Brummer, T., Steinberg, F., \& Reinheckel, T. (2020). Cathepsin D deficiency in mammary epithelium transiently stalls breast cancer by interference with mTORC1 signaling. Nature Communications, 11(1). https://doi.org/10.1038/s41467-020-18935-2

Lubis, S. L., Lubis, H. M. N. D., \& Lukito, H. J. S. (2012). Perbedaan Tampilan Cathepsin D pada Berbagai Grade Histo- patologi Karsinoma Duktus Invasif Payudara. 21(2), 5-10.

Masson, O., Bach, A. S., Derocq, D., Prébois, C., Laurent-Matha, V., Pattingre, S., \& LiaudetCoopman, E. (2010). Pathophysiological functions of cathepsin D: Targeting its catalytic activity versus its protein binding activity? Biochimie, 92(11), 1635-1643. https://doi.org/10.1016/j.biochi.2010.05.009

Minarowska, A., Minarowski, Ł., Karwowska, A., \& Gacko, M. (2007). Regulatory role of cathepsin D in apoptosis. Folia Histochemica et Cytobiologica, 45(3), 159-163. https://doi.org/10.5603/4519

Park, K. C., Dharmasivam, M., \& Richardson, D. R. (2020). The role of extracellular proteases in tumor progression and the development of innovative metal ion chelators that inhibit their activity. International Journal of Molecular Sciences, 21(18), 1-22. https://doi.org/10.3390/ijms21186805

Reinheckel, T., Gocheva, V., Peters, C., \& Joyce, J. A. (2008). Roles of cysteine proteases in tumor progression: Analysis of cysteine cathepsin knockout mice in cancer models. Cancer Degrad, 281-304. https://doi.org/10.1007/978-0-387-69057-5_15

Sung, H., Ferlay, J., Siegel, R. L., Laversanne, M., Soerjomataram, I., Jemal, A., \& Bray, F. (2021). Global Cancer Statistics 2020: GLOBOCAN Estimates of Incidence and Mortality Worldwide for 36 Cancers in 185 Countries. CA: A Cancer Journal for Clinicians, 71(3), 209-249. https://doi.org/10.3322/caac.21660

Tan, G.-J., Peng, Z.-K., Lu, J.-P., \& Tang, F.-Q. (2013). Cathepsins mediate tumor metastasis. World Journal of Biological Chemistry, 4(4), 91. https://doi.org/10.4331/wjbc.v4.i4.91

Tobias, J., \& Hochhauser, D. (2009). Cancer and its Management: Sixth Edition. 
Indonesian Journal of Health Science

Volume 1 No. 2, Desember 2021

https://doi.org/10.1002/9781444306361

Xu, H., Bao, K., Tang, S., Ai, J., Hu, H., \& Zhang, W. (2017). Cyanobacterial peptides as a prototype for the design of cathepsin D inhibitors. Journal of Peptide Science, 23(9), 701706. https://doi.org/10.1002/psc.3014 